\title{
OLAHRAGA DAPAT MENINGKATKAN FUNGSI KOGNITIF MELALUI MODULASI EPIGENETIK EKSPRESI GEN BRAIN- DERIVED NEUROTROPHIC FACTOR (BDNF)
}

\author{
Nila Wahyuni ${ }^{1}$, Made Hendra Satria Nugraha ${ }^{2}$, Indira Vidiari Juhanna ${ }^{3}$ \\ 1, 2,3 Program Studi Fisioterapi Fakultas Kedokteran Universitas Udayana \\ Email:wahyuninila08@gmail.com
}

\begin{abstract}
ABSTRAK
Olahraga dapat meningkatkan fungsi kognitif dan memperlambat terjadinya neurodegenerasi, namun mekanisme yang mendasari hal tersebut belum diketahui dengan pasti. Tujuan dari penulisan ini adalah untuk mengetahui mekanisme olahraga dalam meningkatkan fungsi kognitif ditinjau dari aspek biomolekular. Adapun metode penulisan yang digunakan adalah dengan studi literatur artikel mengenai manfaat olahraga dalam meningkatkan fungsi kognitif yang ditinjau dari aspek biomolekular. Fungsi kognitif adalah suatu fungsi yang berkaitan dengan persepsi, proses belajar, konsentrasi, daya ingat dan problem solving. Olahraga bermanfaat untuk meningkatkan fungsi kognitif yang dimediasi oleh suatu neurotropin yaitu brain-derived neurotrophic factor (BDNF). BDNF berperan dalam plastisitas saraf serta penting dalam eksitabilitas saraf dan khususnya dalam proses belajar dan daya ingat. Olahraga dapat meningkatkan fungsi kognitif dengan menginduksi peningkatan ekspresi BDNF yang terjadi melalui mekanisme perubahan regulasi epigenetik. Perubahan regulasi epigenetik yang terjadi oleh karena olahraga adalah melalui metilasi DNA yang menyebabkan peningkatan ekspresi mRNA BDNF di hippocampus. Perubahan regulasi epigenetik oleh karena olahraga yang juga dapat meningkatkan ekspresi mRNA BDNF adalah modifikasi histone. Peningkatan ekspresi mRNA di hippocampus dapat meningkatkan plastisitas sinaps di area hippocampus sehingga meningkatkan transmisi sinaps yang dapat menyebabkan peningkatan ekspresi molekul-molekul yang berkaitan dengan proses belajar dan daya ingat.
\end{abstract}

Kata kunci : Olahraga, Brain-derived neurotrophic factor (BDNF), Epigenetik.

\section{EXERCISE IMPROVE COGNITIVE FUNCTION TROUGH EPIGENETIC MODULATION BRAIN DERIVED NEUROTROPHIC FACTOR (BDNF) GENE EXPRESSION}

\begin{abstract}
Exercise may improve cognitive function and slow the onset of neurodegeneration, but the underlying mechanism had not yet known certainly. The purpose of this paper is to know the mechanism of exercise in improving cognitive function in terms of biomolecular aspects. The method of this paper is literature study of articles about the benefits of exercise in improving cognitive function in terms of
\end{abstract}


biomolecular aspects. Cognitive function is a function related to perception, learning process, concentration, memory and problem solving. Exercise is useful for improving cognitive function mediated by a neurotropin-brain brain-derived neurotrophic factor (BDNF). BDNF has important role in neural plasticity, nerve excitability, and especially in learning process and memory improving. Exercise can improve cognitive function by inducing increased BDNF expression that occurs through the mechanism of epigenetic regulatory change. The change in epigenetic regulation caused by exercise through DNA methylation, which increase the expression of BDNF mRNA in the hippocampus. The change in epigenetic regulation caused by exercise, which also increase the expression of BDNF mRNA is a histone modification. The increased expression of mRNA in the hippocampus is not only increase synapse plasticity in the hippocampus area but also synapse transmission, which lead to the increasing of molecules expression related to learning and memory.

Keywords: Sport, Brain-derived neurotrophic factor (BDNF), Epigenetic.

\section{PENDAHULUAN}

Olahraga adalah aktivitas fisik yang dapat memperlambat terjadinya penurunan fungsi kognitif ${ }^{1}$. Olahraga dapat memberikan manfaat sebagai neuroprotektif dimana proses penurunan fungsi kognitif oleh karena proses aging dapat dicegah dengan berolahraga secara rutin ${ }^{2}$. Olahraga dapat meningkatkan neurogenesis, sinaptogenesis, angiogenesis dan modulasi kadar neurokimia di dalam otak $^{3}$. Manfaat olahraga tersebut dimediasi oleh suatu neurotropin di dalam otak yaitu brain-derived neurotrophic factor (BDNF), suatu neurotropin yang banyak terdapat di area hippocampus. BDNF berperan dalam plastisitas saraf yang sangat penting dalam kasus trauma otak dan juga fungsi kognitif dan daya ingat. Peningkatan ekspresi BDNF dapat meningkatkan survival sel saraf di area nigrostriatal dan area kortkes cerebri lainnya ${ }^{4}$. Olahraga menyebabkan terjadinya peningkatan kadar BDNF di hippocampus sehingga dapat meningkatkan fungsi kognitif ${ }^{5}$. Berdasarkan penelitian oleh Jeon, Y.K., et al (2017), olahraga aerobik dengan intensitas sedang hingga berat dalam jangka waktu lama dapat meningkatkan kadar BDNF serum dan fungsi kognitif pada remaja ${ }^{6}$. Peningkatan BDNF berhubungan dengan peningkatan plastisitas sinaps di area hippocampus sehingga meningkatkan transmisi sinaps yang dapat menyebabkan peningkatan ekspresi molekul-molekul yang berkaitan dengan proses belajar dan daya ingat $^{7}$. Peningkatan ekspresi BDNF oleh karena olahraga terjadi melalui mekanisme perubahan regulasi epigenetik $^{8}$.

\section{METODE}

Metode penulisan yang digunakan adalah dengan studi literatur artikel mengenai manfaat olahraga dalam meningkatkan fungsi kognitif yang ditinjau dari aspek biomolekular.

\section{PEMBAHASAN}

Olahraga dapat meningkatkan fungsi kognitif dengan menginduksi peningkatan ekspresi gen BDNF yang terjadi melalui mekanisme perubahan regulasi epigenetik ${ }^{8}$. Secara umum 
perubahan regulasi epigenetik dapat menyebabkan terjadinya perubahan ekspresi beberapa gen. Epigenom terdiri dari modifikasi DNA dan kromatin dimana faktor lingkungan sangat mempengaruhi terjadinya epigenetik sehingga dapat memodulasi ekspresi gen tertentu. Perubahan epigenetik oleh karena olahraga adalah metilasi DNA dan modifikasi histone ${ }^{9}$.

\section{Olahraga dapat meningkatkan ekspresi mRNA Brain-Derived Neurotrophine Factor (BDNF) dengan mempengaruhi metilasi DNA}

Olahraga memegang peranan penting dalam plastisitas otak dan kognitif. Efek tersebut dimediasi oleh suatu neurotropin yang banyak terdapat di area hippocampus dan berperan penting dalam perkembangan sel saraf yaitu Brain-Derived Neurotophic Factor $(\mathrm{BDNF})^{10}$. Olahraga secara teratur dapat memberikan efek positif terhadap mekanisme epigenetik yaitu dengan memodulasi pola metilasi DNA pada manusia $^{11}$. Olahraga menyebabkan efek umpan balik positif melalui regulasi transkripsi yang menyebabkan peningkatan ekspresi mRNA BDNF dan reseptornya yaitu tyrosine kinase receptor $\quad(\mathrm{TrkB})^{4}$. $\quad$ Berdasarkan penelitian oleh Gomez-Pinilla, et al tahun 2011 menunjukkan olahraga selama 1 minggu dapat memberikan efek pada metilasi mRNA BDNF dan modifikasi histone pada jaringan hippocampus tikus muda ${ }^{12}$. Peningkatan ekspresi mRNA BDNF setelah berolahraga salah satunya terjadi oleh karena modulasi epigenetik yaitu perubahan pada metilasi $\mathrm{DNA}^{13}$. Olahraga dapat meningkatkan stadium hipometilasi (menurunkan metilasi
CpG) gen promoter BDNF. Metilasi DNA memegang peranan penting dalam remodeling kromatin di dalam otak dan juga berperan dalam menekan transkripsi dan fungsi $\mathrm{BDNF}^{14}$. Olahraga dapat menginduksi hipometilasi promoter IV BDNF yang menyebabkan peningkatan ekspresi mRNA BDNF di area hippocampus ${ }^{15,16}$. Transkripsi promoter IV BDNF ditekan oleh methyl-CpG-binding protein (MeCP2) pada saat metilasi DNA ${ }^{17}$. Olahraga menginduksi pelepasan glutamate yang menstimulasi NMDA-R (N-methyl-D-aspartate receptor) yang menyebabkan masuknya kalsium ke neuron post sinaps. Peningkatan kalsium di neuron post sinaps mengaktivasi calcium-calmodulindependent protein kinase II (CaMKII $)^{18 .}$ Calcium-calmodulin-dependent protein kinase II (CaMKII) yang menyebabkan terjadinya fosforilasi MeCP2 sehingga terbentuk phospho-Me-CP2. PhosphorMe-CP2 akan terpisah dari promoter BDNF dan terjadilah transkripsi $\mathrm{BDNF}^{19}$.

\section{Olahraga dapat meningkatkan ekspresi mRNA Brain-Derived Neurotrophine Factor (BDNF) melalui modifikasi histone}

Struktur protein histone ditandai dengan core domain globular dan $\mathrm{N}$ terminal tail yang peka terhadap berbagai modifikasi post translasi ${ }^{18}$. Modifikasi histone terlibat dalam berbagai modifikasi post translasi pada bagian histone yang kaya akan lysine. Modifikasi yang dapat terjadi yaitu fosforilasi, ubikuitinasi, metilasi dan asetilasi. Setiap mofifikasi tersebut memiliki target asam amino yang berbeda-beda dan menimbulkan efek 
yang berbeda pada transkripsi gen ${ }^{20}$. Asetilasi histone dapat menginduksi kromatin aktif sehingga terjadilah transkripsi gen $\mathrm{BDNF}^{21}$. Histone yang terlibat dalam plastisitas saraf adalah histone 3 dan $4^{22}$. Penelitian GomezPinilla et al menunjukkan bahwa olahraga dapat meningkatkan histone yang terasetilasi pada hippocampus yang memfasilitasi terjadinya transkripsi $\mathrm{BNDF}^{12}$. Asetilasi histone yang mempengaruhi ekpresi gen dipengaruhi oleh aktivitas hystone acetyltransferase (HAT) dan hystone deacetylase (HDAC). HAT adalah enzim yang mengkatalisasi proses transfer gugus asetil dari acetyl-coenzim A ke residu lysine dari histone, sedangkan HDAC berfungsi untuk menyingkirkan gugus asetil dari histone $^{18}$. Penelitian oleh Elsner menunjukkan bahwa olahraga yang dilakukan pada tikus muda selama 2 minggu dapat mempengaruhi enzimenzim HAT dan HDAC di hipoccampus. Olahraga menyebabkan asetilasi histone 3 (H3) dengan mengurangi ekspresi mRNA HDAC5. Asetilasi H3 juga terjadi karena phosphor-cyclic AMP-response element binding protein yang me-recruit CREB (c-AMP response element binding protein) yang bersifat meningkatkan aktivitas HAT. Peningkatan asetilasi H3 akan menyebabkan peningkatan ekpresi gen $\mathrm{BDNF}^{23}$. Olahraga dapat memicu plastisitas sinaptik dan perbaikan daya ingat dengan mengubah keseimbangan aktivitas enzim HAT/HDAC ${ }^{18}$. Mekanisme olahraga dalam meningkatkan fungsi kognitif melalui efek pada metilasi DNA dan modifikasi histone dapat dilihat pada gambar 1 . 


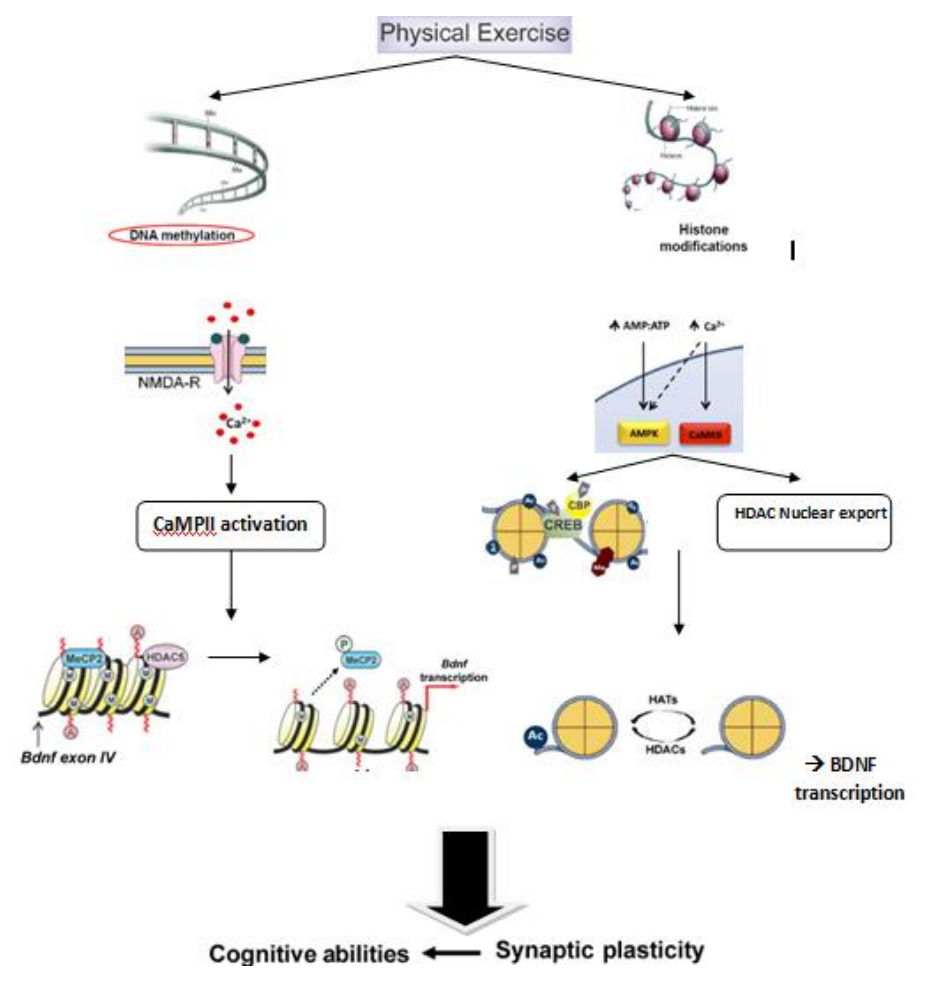

Gambar 1. Mekanisme olahraga dalam meningkatkan fungsi kognitif melalui efekpada metilasi DNA dan modifikasi histone ${ }^{12,18,20}$

\section{KESIMPULAN}

Berdasarkan uraian di atas, maka dapat disimpulkan :

1. Olahraga dapat meningkatkan fungsi kognitif dengan menginduksi peningkatan ekspresi BDNF.

2. Olahraga meningkatkan ekspresi BDNF terjadi melalui perubahan regulasi epigenetik.

3. Perubahan regulasi epigenetik yang diinduksi oleh olahraga dengan mempengaruhi metilasi DNA promoter IV gen BDNF dan modifikasi histone3 (H3).

\section{DAFTAR PUSTAKA}

1. Laurin, D., Verreault, R., Lindsay, J., MacPherson, K., Rockwood, K. 2001. Physical activity and risk of cognitive impairment and dementia in elderly persons. Arch Neurol;58:498-504.
2. Aguiar, A.S., Speck, A.E., Prediger, R.D., Kapczinski, F., Pinho, R.A. 2008. Downhill training upregulates mice hippocampal and striatal brainderived neurotrophic factor levels. J. Neural Transm. 115, 1251-1255.

3. Berchicci, M., Lucci, G., and Di Russo. 2013. Benefits of Physical Exercise on the Aging Brain: The Role of the Prefrontal Cortex. J Gerontol A Biol Sci Med Sci. 2013 November;68(11):1337-1341

4. da Silva , P.G.C., Domingues ,D.D., de Carvalho,L.A., Allodi , S., Correa, C.L. 2016. Neurotrophic factors in Parkinson's disease are regulated by exercise:Evidence-based practice. Journal of the neurological science. Elsevier. pp 5-15. 
5. Berchtold, N., Castello, N., Cotman,C. 2010. Exercise and time-dependent benefits to learning and memory. Neurosciences. 167(3):588-97

6. Jeon, Y.K., and Ho Ha., C. 2017. The effect of exercise intensity on brain derived neurotrophic factor and memory in adolescents. Environmental Health and Preventive Medicine. pp. 22:27.

7. Vicario-Abejon, C., Owens, D., McKay, R., Segal, M. 2002. Role of neurotrophins in central synapse formation and stabilization. Nat Rev Neurosci. 3(12):965-74.

8. Feng, J., Fouse, S., Fan, G. 2007. Epigenetic regulation of neural gene expression and neuronal function. Pediatr Res 61(5 Pt 2):58R-63R.

9. Denham, J., Marques, F.Z., Brendan, J. O'Brien, Fadi, J. Charchar. 2013. Exercise: Putting Action into Our Epigenome. Springer International Publishing Switzerland. Sport Medicine Journal.

10. Stathopoulos, J.N., Tzanninis, JG.,Philippou, A., Koutsilieris, M. 2013. Epigenetic regulation on gene expression induced by physical exercise. $\mathbf{J}$ Musculoskelet Neuronal Interact; 13(2):133-146.

11. Archer, T. 2015. Epigenetic Changes Induced by Exercise. Journal of Reward Deficiency Syndrome.

12. Gomez-Pinilla, F, Zhuang, Y, Feng, J et al .2011. Exercise impacts brain-derived neurotrophic factor plasticity by engaging mechanisms of epigenetic regulation. Eur $\mathbf{J}$ Neurosci 33 (3):383-390

13. Vaynman S, Ying Z, GomezPinilla F. Interplay between brain-derived neurotrophic factor and signal transduction modulators in the regulation of the effects of exercise on synaptic-plasticity.

Neuroscience 2003;122(3):64757.

14. Barres, R., Yan, J., Egan, B., et al. 2012. Acute exercise remodels promoter methylation in human skeletal muscle. Cell Metab 15(3):405-411

15. Martinowich., K., Hattori, D., $\mathrm{Wu}, \mathrm{H}$., Fouse, S., He, F., Hu, Y., Fan, G. \& Sun, Y.E. 2003. DNA methylation-related chromatin remodeling in activitydependent BDNF gene regulation. Science, 302, 890893.

16. Ding, Q., Vaynman, S., Souda, P., Whitelegge, J.P. \& GomezPinilla, F. 2006. Exercise affects energy metabolism and neural plasticity-related proteins in the hippocampus as revealed by proteomic analysis. Eur. J. Neurosci., 24,1265-1276.

17. Vaynman, S., Ying, Z. \& Gomez-Pinilla, F. 2004. Hippocampal BDNF mediates the efficacy of exercise on synaptic plasticity and cognition. Eur.J. Neurosci., 20, 2580-2590.

18. Fernandes, J., Arida, R.M., Gomez-Pinilla, F. 2017. Physical exercise as an epigenetic modulator of brain plasticity and cognition. Elsevier Neuroscience and
Biobehavioral Review 80. pp
443-456.

19. Chen, W.G., Chang, Q., Lin, Y., Meissner, A., West, A.E., 
Griffith, E.C., Jaenisch, R. \& Greenberg, M.E. 2003. Depression of BDNF transcription involves calciumdependent phosphorylation of MeCP2. Science, 302, 885-889.

20. McGee, S.L., \& Hargreaves, M. 2011. Histone modifications and exercise adaptations. $J$ Appl Physiol 110: 258-263.

21. Tsankova, N.M., Berton, O., Renthal, W., Kumar, A., Neve, R.L. \& Nestler, E.J. 2006. Sustained hippocampal chromatin regulation in a mouse model of depression and antidepressant action. Nat. Neurosci., 9, 519-525.

22. Sweatt, J.D. 2009. Experiencedependent epigenetic modifications in the central nervous system. Biol. Psychiatry, 65, 191-197.

23. Goto, S., Kawakami, K., Naito, H., Katamoto, S., Radak, Z. 2015. Epigenetic Modulation of Gene Expression by Exercise. Reaserach Gate. Chapter 5. 